\title{
Conservative care of the newborn baby
}

\author{
T. H. HUGHES-DAVIES
}

Odstock Hospital, Salisbury, Wiltshire

SUMMARY A method of managing ill and premature babies with little disturbance is described. The results of such care during 1969-76 compare favourably with those achieved by more intensive and active intervention.

Small or ill babies dislike being disturbed, and in the mid 1960s it seemed to me that intervention did harm as often as it did good. Here is described a way of leaving babies alone and its results.

\section{Method}

1. All babies are nursed prone and head up on an apnoea mattress. In this position the pharynx clears itself, the stomach is self winding, the lower oesophagus is protected by the gastric air bubble, and the brain drains uncongested.

2. The baby is never left naked but is covered at least by a towel napkin to reduce radiant heat loss. At night and on cold days, the nursery curtains are drawn.

3. A nasal tube is passed and feeding and watering begun within half an hour of admission. Feeds are given from outside the incubator without touching the baby. Babies fed only milk cannot satisfy their thirst and hunger independently as older children do. Most cope, but some become obese in an attempt to get enough water, or become oversalted, uraemic, and anorexic from a failure to do so. We therefore follow the example of other mammals by offering water 3 times a day to all babies. Those not sucking get their water down the tube in a volume equal to one of their milk feeds, with an increase if they are hot or uncomfortable. This is usually given as $10 \%$ glucose to the smaller babies as prophylaxis against hypoglycaemia, but water would probably be as good and perhaps safer, although we have had no trouble. Human milk expressed or from the breast, is used for the smaller babies and, if available, for the rest; but all milks seem well tolerated with supplementary water. For convenience we used prebottled milk when it became available. The quantity is increased from about $60 \mathrm{ml} / \mathrm{kg}$ per day on the 1st

Central Hospital, Honiara

T. H. HUGHES-DAVIES, consultant paediatrician day to $120 \mathrm{ml} / \mathrm{kg}$ on the $3 \mathrm{rd}$, up to $200 \mathrm{ml} / \mathrm{kg}$ by the 7 th, depending on the state of the baby and the judgement of the sister.

4. At the first suspicion of respiratory difficulty an $x$-ray of the chest is taken, and acidaemia is anticipated and averted by adding sodium bicarbonate to the feed at a rate of $\frac{1}{2}-1 \mathrm{mmol} / \mathrm{h}$. The carbon dioxide formed leaves by the oesophagus, so the neutralisation is independent of lung function. The head up tilt is increased to $30^{\circ}$ in the hope of reducing collapse of apical alveoli during expiration.

5. Blood glucose is checked by Dextrostix, at first every hour; and bilirubin as necessary by heel prick. No venous samples are taken except for culture if an infection is suspected. Nothing is given intravenously, except occasionally during initial resuscitation, or later for the correction of anaemia.

6. A stream of piped air, or air and oxygen, is directed from a funnel at the baby's face as a stimulus against apnoeic attacks. The concentration of oxygen is checked regularly, and enough given to prevent cyanosis.

7. Ventilators and positive pressure devices are not used, nor is phototherapy.

8. Isolation is kept to a minimum, and depends largely on the incubator and on hand washing. The nursery is open to mothers and relatives who are encouraged to help with the babies' care from the start. Masks and overshoes are not used, and gowns only for convenience; gloves are used for passing tubes.

9. During exchange transfusion, the umbilical catheter is sandwiched between two layers of adhesive film covering the abdomen, and the baby lies prone and unfettered in his usual position in the incubator.

\section{Results}

In 8 years, 911 babies under $2500 \mathrm{~g}$ were born. This was $6.1 \%$ of all births, and close to the national 
average of $6 \cdot 3 \%$. Of these, in $1974-76,48 \cdot 3 \%$ were between 2500 and $2250 \mathrm{~g}, 20.7 \%$ between 2250 and $2000 \mathrm{~g}, 19.1 \%$ between 2000 and $1500 \mathrm{~g}, 7.9 \%$ between 1500 and $1000 \mathrm{~g}$, and $3.9 \%$ were under 1000 g. The corresponding figures for England and Wales for 1975 were $48 \cdot 2,22 \cdot 8,17 \cdot 9,7 \cdot 4$, and $3 \cdot 5 \%$ respectively. Any larger baby about whom there was concern was also admitted to the nursery, and about one-third of all babies passed through if only for a few hours.

Hypothermia, hypoglycaemia, enterocolitis, pneumothorax, and bleeding and thrombotic complications were seldom met. Exchange transfusion was needed only for haemolytic disease, and there has been no late evidence of kernicterus. Babies with respiratory distress left undisturbed have done well with no late lung disorder. Apnoea has been severe only in babies later found at post-mortem examination to have cerebral haemorrhage from birth trauma. One severely retarded child is partially sighted and has retinal changes which may be related to ventilation with pure oxygen during half an hour's apnoea at birth; he did not need oxygen subsequently.

After discharge the babies were seen if necessary at a clinic held each week in the nursery, where the mothers were at ease and the nurses could see the results of their care. They did well. The few affected children were not those who had caused concern in the first weeks, and most had evidence of an intrauterine infection or some other handicapping condition. Some who had had unduly prolonged resuscitation at birth, and who needed tube feeding for a long time, remained severely retarded-the 'failed stillbirth' group for whom the answer is perhaps to limit initial ventilation for apnoea to $\mathbf{3 0}$ minutes or so, when there is evidence of profound intrapartum anoxia.

Death in the first week is the best defined measure of comparison; the number of deaths and births by weight is shown in Table 1, and the 3-year running average mortality in Table 2 . All deaths are included whether they occurred in the delivery room, in the nursery, or after transfer to another hospital for surgery. Included in the table are the deaths in the first month for England and Wales by weight in 1975; and also deaths among 1017 babies of $<2500$ $\mathrm{g}$ admitted to six neighbouring nurseries in 1975, but it is likely that not all the larger babies are included in these figures.

Among the smaller babies there was an initial rise followed by a steady fall in the mortality. As the care of the babies was unchanged, and the fall much steeper than the national trend, these changes are probably due to improvement in obstetric care. This was reflected in a corresponding fall in the
Table 1 First week deaths and number born, by year and weight

\begin{tabular}{llclll}
\hline Year & \multicolumn{6}{l}{ Weight $(g)$} & & \\
\cline { 2 - 6 } & $1001-1500$ & $1501-2000$ & $2001-2250$ & $2251-2500$ & $>2500$ \\
\hline 1969 & $2 / 12$ & $4 / 22$ & $2 / 29$ & $2 / 32$ & $3 / 1735$ \\
1970 & $7 / 12$ & $5 / 33$ & $0 / 36$ & $3 / 50$ & $4 / 1775$ \\
1971 & $8 / 17$ & $7 / 32$ & $1 / 23$ & $0 / 57$ & $7 / 1763$ \\
1972 & $3 / 4$ & $10 / 26$ & $0 / 32$ & $0 / 46$ & $5 / 1725$ \\
1973 & $1 / 4$ & $3 / 32$ & $1 / 28$ & $1 / 60$ & $7 / 1770$ \\
1974 & $3 / 12$ & $2 / 19$ & $0 / 23$ & $0 / 56$ & $6 / 1795$ \\
1975 & $1 / 2$ & $1 / 17$ & $0 / 26$ & $1 / 53$ & $5 / 1700$ \\
1976 & $1 / 10$ & $2 / 22$ & $0 / 14$ & $1 / 38$ & $3 / 1750$ \\
\hline
\end{tabular}

Table 2 First week mortality percentage by weight3-year running average

\begin{tabular}{|c|c|c|c|c|c|}
\hline \multirow[t]{2}{*}{ Years } & \multicolumn{5}{|l|}{ Weight (g) } \\
\hline & $1001-1500$ & $1501-2000$ & $2001-2250$ & $2251-2500$ & $>2500$ \\
\hline $\begin{array}{l}\text { Salisbury } \\
1969-71 \\
1970-72 \\
1971-73 \\
1972-74 \\
1973-75 \\
1974-76\end{array}$ & $\begin{array}{l}41 \\
55 \\
48 \\
35 \\
28 \\
21\end{array}$ & $\begin{array}{r}18 \\
24 \\
22 \\
19 \\
9 \\
9\end{array}$ & $\begin{array}{l}3 \\
1 \\
2 \\
1 \\
1 \\
0\end{array}$ & $\begin{array}{l}3 \\
2 \\
0 \cdot 6 \\
0 \cdot 6 \\
1 \\
1\end{array}$ & $\begin{array}{l}0 \cdot 3 \\
0 \cdot 3 \\
0 \cdot 3 \\
0 \cdot 3 \\
0 \cdot 3 \\
0 \cdot 3\end{array}$ \\
\hline $\begin{array}{l}\text { England } \\
\text { and Wales } \\
1975\end{array}$ & 45 & 13 & 4 & 2 & \\
\hline $\begin{array}{l}\text { Wessex } \\
\text { neighbours } \\
1975\end{array}$ & 46 & 14 & $\begin{array}{l}2001-2500 \\
3 \cdot 3\end{array}$ & & \\
\hline
\end{tabular}

number of babies who died after 20 minutes or more of apnoea at birth, or who had tentorial tears at post-mortem examination. Of the lethal deformities 19 were in babies $>2500 \mathrm{~g}$ and 8 in smaller ones. Table 3 gives the cause of other deaths by year and weight. Table 4 shows the mortality of very small babies of $<1000 \mathrm{~g}$. This is high, but little different from that of babies born in University College Hospital, London as derived from the figures of Stewart et al. (1977), or from that reported by neighbouring nurseries.

\section{Discussion}

Different hospitals serve different populations, and reliable comparison between methods of care is difficult but should be attempted. The results of conservative treatment presented here seem no worse than those of more intensive care; and it may be that the method will be of use to other small hospitals in this country and overseas. The incidental benefits were considerable; nurses and doctors as well as babies got more rest, and it became practicable if not desirable to run the nursery with one trained and one assistant nurse or less per shift, with 
Table 3 Cause of death other than lethal deformities, prolonged intrapartum asphyxia, and tentorial tears

\begin{tabular}{|c|c|c|c|c|c|}
\hline \multirow[t]{2}{*}{ Year } & \multicolumn{5}{|l|}{ Weight $(g)$} \\
\hline & $1001-1500$ & $1501-2000$ & $2001-2250$ & $2251-2500$ & $>2501$ \\
\hline $\begin{array}{l}\text { Total born (1969-76) } \\
1969\end{array}$ & $\begin{array}{l}73 \\
\text { None }\end{array}$ & $\begin{array}{l}203 \\
\text { Klebsiella pneumoniae }\end{array}$ & $\begin{array}{l}211 \\
\text { None }\end{array}$ & $\begin{array}{l}392 \\
\text { Cerebral bleed }\end{array}$ & $\begin{array}{l}14013 \\
\text { Pyocyaneus } \\
\text { septicaemia }\end{array}$ \\
\hline 1970 & $\begin{array}{l}5 \text { prematurity } \\
1 \text { cerebral bleed }\end{array}$ & $\begin{array}{l}1 \text { cerebral bleed } \\
1 \text { respiratory distress } \\
\text { (twin 2) }\end{array}$ & None & $\begin{array}{l}\text { Cerebral bleed } \\
\text { after prolonged } \\
\text { rupture }\end{array}$ & None \\
\hline 1971 & Prematurity & $\begin{array}{l}1 \text { Escherichia coli } \\
026 \text { enteritis } \\
1 \text { cerebral bleed }\end{array}$ & $\begin{array}{c}\text { Pierre Robin } \\
\text { syndrome }\end{array}$ & None & Posterior fossa bleed \\
\hline 1972 & $\begin{array}{l}\text { Pulmonary } \\
\text { haemorrhage }\end{array}$ & $\begin{array}{l}\text { Respiratory distress } \\
\text { after section for } \\
\text { fetal distress }\end{array}$ & None & None & None \\
\hline 1973 & Prolapsed cord & $\begin{array}{l}\text { Posterior fossa } \\
\text { bleed }\end{array}$ & None & $\begin{array}{l}\text { Respiratory distress } \\
\text { after section for } \\
\text { fetal distress }\end{array}$ & $\begin{array}{l}1 \text { cot death after } \\
\text { section for prolapsed } \\
\text { cord } \\
1 \text { viral pneumonia }\end{array}$ \\
\hline 1974 & Prematurity & $\begin{array}{l}1 \text { admitted moribund } \\
\text { at } 2 \text { hours } \\
1 \text { intrapartum } \\
\text { streptococcal } \\
\text { septicaemia }\end{array}$ & None & None & None \\
\hline 1975 & $\begin{array}{l}\text { Admitted at } 2 \text { hours } \\
\text { with hypothermia } \\
\text { and adrenal bleeds }\end{array}$ & None & None & None & $\begin{array}{l}\text { Septicaemia after } \\
\text { operation for } \\
\text { covered anus }\end{array}$ \\
\hline 1976 & None & None & None & None & None \\
\hline
\end{tabular}

Table 4 Very small babies

\begin{tabular}{|c|c|c|c|c|}
\hline & Born & Died & $\begin{array}{l}\text { Mortality } \\
(\%)\end{array}$ & Weight \\
\hline $\begin{array}{l}\text { Salisbury } \\
\quad(1969-76) \\
\text { UCH, London } \\
(1966-75)\end{array}$ & 11 & 11 & $\begin{array}{l}100 \\
100\end{array}$ & $₹ 750 \mathrm{~g}$ \\
\hline $\begin{array}{l}\text { England and Wales } \\
\text { (1975) } \\
\text { Wessex neighbours } \\
(1975) \\
\text { UCH, London } \\
(1966-70) \\
(1971-75)\end{array}$ & $\begin{array}{l}36 \\
33\end{array}$ & $\begin{array}{l}29 \\
26\end{array}$ & $\begin{array}{l}79 \\
74\end{array}$ & $₹ 1000 \mathrm{~g}$ \\
\hline $\begin{array}{l}\text { Salisbury } \\
\quad(1969-76)\end{array}$ & 21 & 16 & 76 & $\begin{array}{l}751-1000 \\
\text { (all ages) }\end{array}$ \\
\hline $\begin{array}{l}\text { UCH, London } \\
\text { (1966-75) } \\
\text { Salisbury } \\
\text { (1969-76) } \\
\text { UCH, London } \\
(1966-75)\end{array}$ & 21 & 16 & $\begin{array}{l}76 \\
80\end{array}$ & $\begin{array}{l}751-1000 \\
\text { (<30 } \\
\text { weeks) }\end{array}$ \\
\hline
\end{tabular}

medical cover from a single doctor who also had responsibility for all the other paediatric work in the hospital.

It has been suggested that small babies should be transferred to regional centres. Table 4 shows that there has been little change in the mortality of very small babies in successive 5-year periods in one of the best of these; and that when babies of 30 weeks' gestation or more are removed the mortality differs little from the national average. Our experience suggests that improvement in perinatal mortality depends largely on the care of the mother and her baby before and during birth.

I am indebted to Sister Rowlands and the staff of Salisbury special care nursery for their help, and to neighbouring paediatricians for their kindness in providing figures.

\section{Reference}

Stewart, A. L., Turcan, D. M., Rawlings, G., and Reynolds, E. O. R. (1977). Prognosis for infants weighing $1000 \mathrm{~g}$ or less at birth. Archives of Disease in Childhood, 53, 97-104.

Correspondence to Dr T. H. Hughes-Davies, Central Hospital, Honiara, Solomon Islands.

Received 4 May 1978 